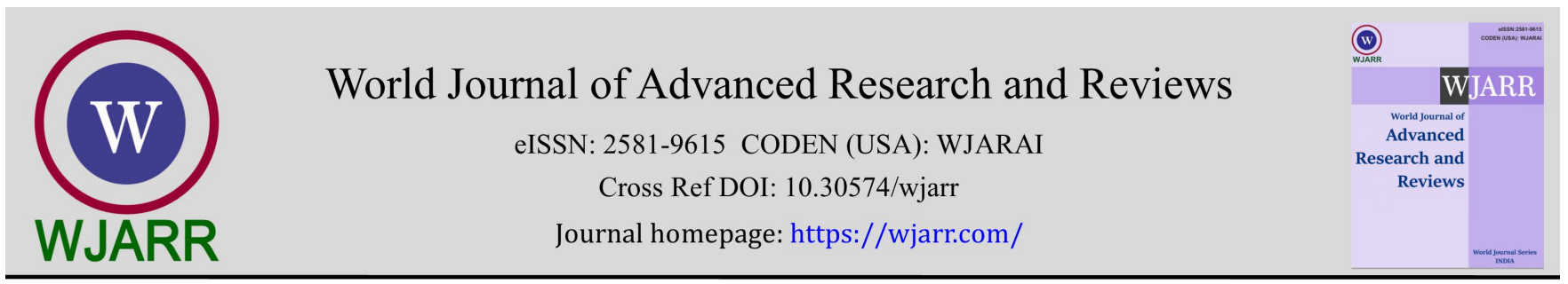

(RESEARCH ARTICLE)

Check for updates

\title{
Variation among pineapple half-sibs and selecting genitors based on potential genetic divergence
}

José Severino de Lira Júnior 1, ${ }^{*}$, João Emmanoel Fernandes Bezerra ${ }^{2}$, Vania Trindade Barrêtto Canuto ${ }^{2}$ and Diana Andrade dos Santos ${ }^{2}$

${ }^{1}$ Experimental Station of Itambé, Department of Research and Development, Agronomic Institute of Pernambuco - IPA, Itambé, Pernambuco State, Brazil.

${ }^{2}$ Administrative headquarters, Department of Research and Development, Agronomic Institute of Pernambuco - IPA, Recife, Pernambuco State, Brazil.

World Journal of Advanced Research and Reviews, 2021, 10(03), 289-301

Publication history: Received on 08 May 2021; revised on 15 June 2021; accepted on 17 June 2021

Article DOI: https://doi.org/10.30574/wjarr.2021.10.3.0278

\begin{abstract}
Knowledge about variation and relative importance of agronomic traits for genetic divergence studies can reveal useful information to guide the breeding programs. The objective of this study was to evaluate the phenotypic variation, and select of pineapple half-sib seedlings based on genetic divergence of fruit and plant traits. 'Pérola' cultivar (female genitor) received a pollen mix as from cultivars 'MD-2', 'BRS Imperial' and 'BRS Vitória' (male genitors). Four hundred twenty-nine $F_{1}$ individuals propagated from seeds were evaluated under field conditions. Descriptive statistics, Singh's (1981) relative contribution, and Tocher's cluster optimization methods based on the distances matrix were estimated. Coefficients of variation ranged from $9.89 \%$ to $63.79 \%$. Regarding total variance, fruit traits grouped $52.69 \%$, while plant traits accumulated $47.30 \%$. These results demonstrated that evaluated traits contribute for half-sib progeny relative discrimination and that none of them should be discarded for studies of diversity. Among the 12 heterotic clusters formed, group VII, IX and VIII are recommended to compose hybridization blocks and evaluation cycles of phenotypic stability for use per se. These groups have a broad heterotic potential, and desirable agronomic traits, mainly regarding to high means for fruit mass without crown (FMWC) upper than 4,000g and soluble solids content (SSC) around $20-21^{\circ}$ Brix, which can be used by the IPA's pineapple breeding program.
\end{abstract}

Keywords: Ananas comosus; Plant breeding; Variance; Dissimilarity; Clustering

\section{Introduction}

Pineapple (Ananas comosus var. comosus) is a fruit that standing out among the most cultivated tropical fruit species and high economic importance around the world. Distributed about 80 countries, the world pineapple production was estimated at 28,179,348 tons, harvested in a wide area of 1,125,307 ha, in 2019 [1]. The largest producing of 3,328,100 tons was the Costa Rica, follow of 2,747,856 tons (Philippines) and 2,426,526 tons (Brazil).

The main pineapple cultivar planted in Brazil, known as 'Pérola' or 'Branco de Pernambuco' [2], it has vigorous growth, with long leaves and dark green color. Its fruit has a conical shape, mainly directed to the domestic fresh fruit market. Average fruit weight is 1.6kg; the pulp has a cream-white color with abundant juice and intense aroma, and total soluble solids are between $13-16^{\circ} \mathrm{Brix}$. This cultivar is highly susceptible to fusariosis, a fungal disease (Fusarium guttiforme) that severely affects Brazilian production.

\footnotetext{
* Corresponding author: José Severino de Lira Júnior

Experimental Station of Itambé , Department of Research and Development, Agronomic Institute of Pernambuco - IPA, Itambé, Pernambuco State, Brazil.
} 
In Brazil, the development of new pineapple cultivars aims to combine genes that control resistance to fusariosis and leaf margins without spines in a single plant, as well as genes of dozens of other traits related to improvement of fruit quality and greater yield stability $[3,4,5]$.

Routinely, pineapple breeding programs generates and processes data bases with thousands of observations referring to dozens of traits related to the productivity and fruit quality, aiming to identify unexplored patterns or behaviors in this broad data set $[3,6,7]$. Knowledge about phenotypic variation of agronomic traits and diversity among genotypes based on dissimilarity coefficients can reveal useful information to guide breeding programs.

In general, analysis of the predictive genetic diversity aims identify more divergent individuals with high averages for important agronomic traits. Its importance is highlighted because more divergent individuals are the most suitable to produce a high heterotic effect. The degree of genetic diversity expresses some measure or coefficient of dissimilarity based on morphological, physiological or molecular differences between individuals $[8,9,10]$.

The expectation of heterosis manifested among descendants is a function of the gene dominance effects to the interest trait and square of the genetic frequencies difference of their parents, in addition to epstatic effects, which are generally neglected $[11,12]$.

These studies are applicable to identify promising $\mathrm{F}_{1}$ individuals with wide divergence and higher mean for those traits related to the fruit quality and plant productivity. After this step these selected individuals can be used for cultivation per se and/or like a potential genitor in hybridization plans $[6,7,13]$.

The Brazilian pineapple breeding programs have focused on recombining alleles of qualitative traits that control spineless leaf margin and resistance to fusariosis (Fusarium guttiforme) $[3,4,5]$. However, other many quantitative traits should be also considered for the selection strategies, associated to fruit quality and higher production stability.

The objective of this study was to evaluate the phenotypic variation of fruit and plant traits among pineapple half-sibs, and select individuals based on potential genetic divergence for genitors in hybridization plans of the breeding program of the Agronomic Institute of Pernambuco - IPA, Brazil.

\section{Material and methods}

The field trial was carried out in the Experimental Station of Itambé, Pernambuco State, Brazil (lat $7^{\circ} 24^{\prime} 16.80^{\prime \prime}$ S, long $35^{\circ} 10^{\prime} 54.00^{\prime \prime} \mathrm{W}$, alt $190 \mathrm{~m}$ asl) belonging to the Agronomic Institute of Pernambuco (IPA). The municipality of Itambé is located in North region of the 'Zona da Mata'. The climate of this region is hot and humid As (Köppen) with $25^{\circ} \mathrm{C}$ of mean annual temperature, and 1.200 mm.year $^{-1}$ of mean rainfall.

\section{$2.1 \quad$ Plant materials}

Plant material was represented by 429 half-sib individuals of pineapple (Ananas comosus var. comosus). These individuals (seedlings) propagated from seed were developed by the IPA's Pineapple Genetic Breeding Program. Seedlings were obtained via pollination using 'Pérola' as female genitor, that it received a pollen mix from 'MD-2', 'BRS Imperial' and 'BRS Vitória' as male genitors.

Table 1 Agronomic information about the cultivars used as genitors

\begin{tabular}{|l|l|l|l|l|}
\hline \multicolumn{1}{|c|}{ Traits } & \multicolumn{4}{c|}{ Cultivars } \\
\hline & 'Pérola' & 'MD-2' & 'BRS Imperial' & 'BRS Vitória' \\
\hline Fusariosis & Susceptible & Susceptible & resistant & Resistant \\
\hline Fruit mass(kg) & $0.9-1.6$ & $1.3-2.5$ & $0.9-1.3$ & 1.5 \\
\hline Soluble solids $\left({ }^{\circ}\right.$ Brix) & $13-16$ & $15-17$ & $14-18$ & 15.8 \\
\hline Pulp color & White & Yellow & yellow & White \\
\hline Fruit shape & Conical & cylindrical & cylindrical & Cylindrical \\
\hline Leaf margin & Spiny & spiny tip or base & piping & Piping \\
\hline
\end{tabular}


These cultivars were chosen due to their contrasting and complementary agronomic traits (Table 1). Regarding the origin these cultivars, 'Pérola' is a pre-Columbian plant, cultivated by indigenous peoples before Europeans arrived in America.

Regarding the origin these cultivars; 'Pérola' is a pre-Columbian plant, cultivated by indigenous peoples before Europeans arrived in American continent; 'MD-2' is across between 'PRI 58-1184' and 'PRI 59-443', the parentage includes 'Smooth Cayenne' and others several cultivars. It was first marketed by Del Monte Inc. in 1996; 'BRS Imperial' is a cross between 'Perolera' and 'Smooth Cayenne' performed by EMBRAPA and released 2003; 'BRS Vitória' is a cross between 'Primavera' and 'Smooth Cayenne' performed by EMBRAPA and released in $2006[14,15]$.

\subsubsection{Cultivation of genitor plants}

In 2014 May, genitors were planted in plastic bucket of volume for $10 \mathrm{~L}$, containing soil (2/3) and cattle manure $(1 / 3)$ as substrate, and $10 \mathrm{~g}$ of simple superphosphate per $10 \mathrm{~L}$ of the mixture was added, that were kept in greenhouse with micro drip irrigation (Figure 1). Twenty slips to each cultivar-genitor was used, being one slip per plastic bucket.

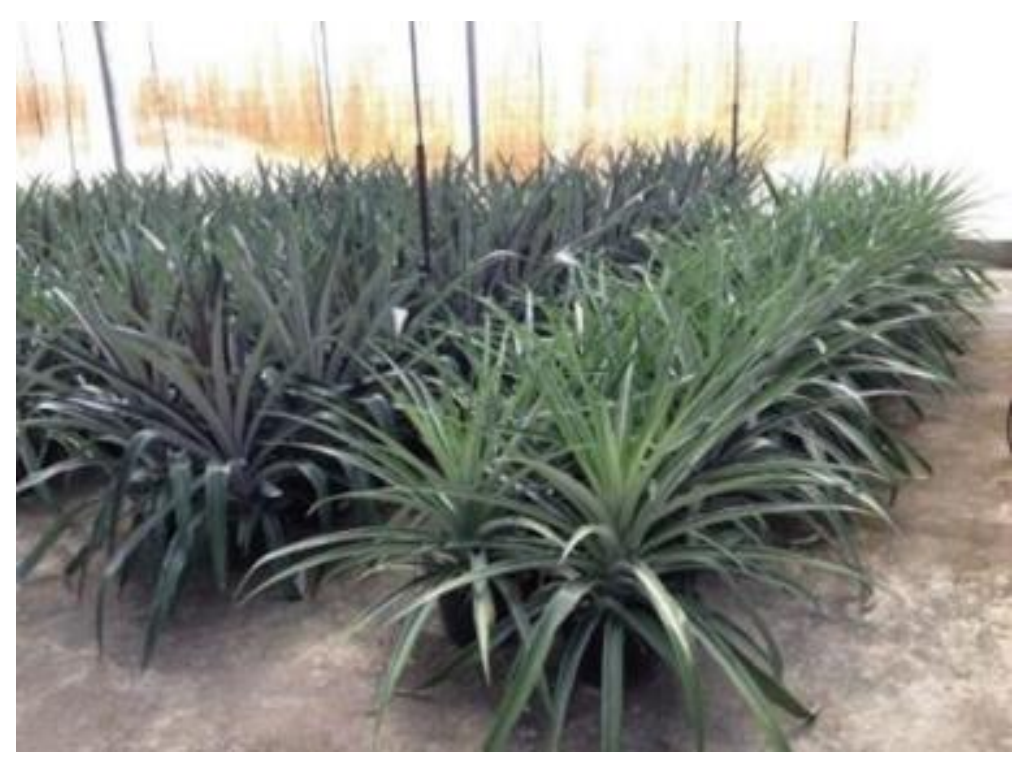

Figure 1 Genitor plants cultivated in plastic bucket for cross pollination. IPA's Pineapple Genetic Breeding Program. Photo Lira Júnior, J. S.

\subsubsection{Floral induction treatment}

When genitors completed 11 months old, floral induction treatment was performed in Abril 2015. Calcium carbide via liquid form as floral inductor was used. The appearance of inflorescences occurred between 2015 June and 2015 July.

\subsubsection{Pollination}

Pollination in the morning (from 6 am to 9 am), daily, until closure all flowers was performed (Figure 2). Both male and female genitor inflorescences were protected with kraft paper bag to avoid pollen contamination of unknown origin. Anthers were collected in flowers from male genitors ('MD-2', 'BRS Imperial' and 'BRS Vitória') and rubbed lightly over stigma of the female genitor flowers. After pollination, inflorescences were protected again. 


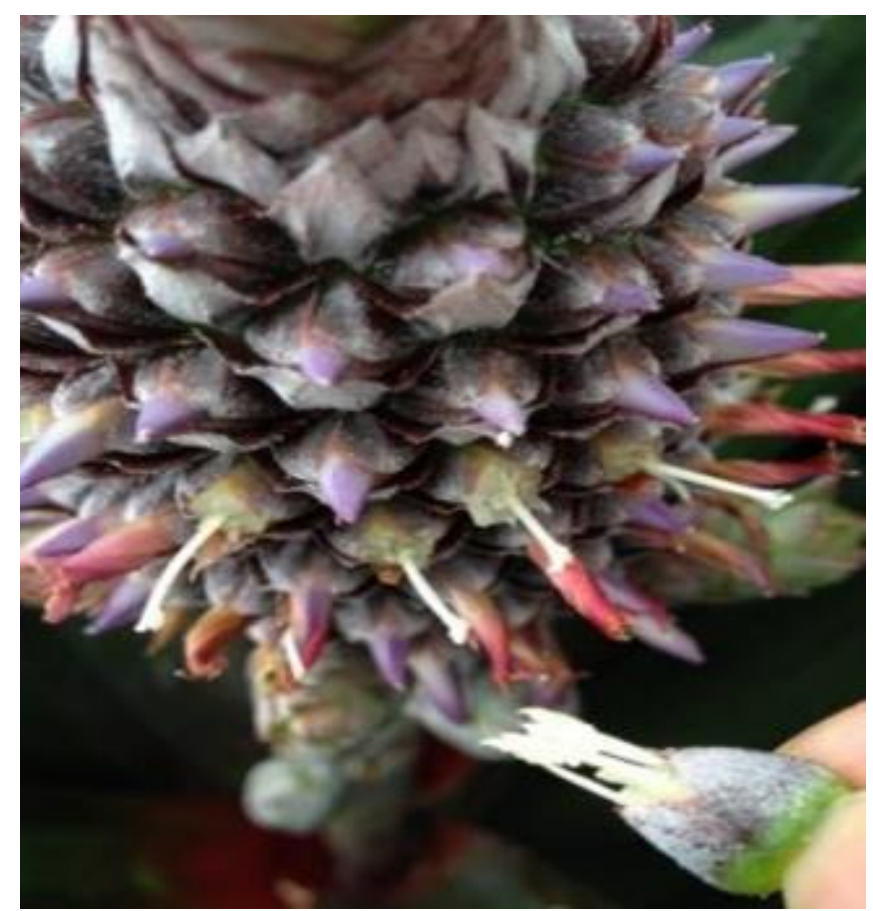

Figure 2 Pollination of Pérola's emasculated flowers (Female genitor). IPA's Pineapple Genetic Breeding Program. Photo Lira Júnior, J. S

\subsubsection{Germination and acclimatization}

In December 2015, seeds extracted in the over-ripe 'Perola' fruits (Figure 3A). These seeds were washed in a sieve under running water and dried in kiln at $37^{\circ} \mathrm{C}$ for 48 hours.

In January 2016, seeds in plastic trays with blotting paper as a substrate and moistened with distilled water were sowed. Trays were sealed with PVC film and kept inside a seed germination chamber with $25{ }^{\circ} \mathrm{C}$ and under continuous light. Germination for up to 75 days after sowing was verified. Germinated seeds that emitted radicles when visible to naked eye were considered (Figure 3B).

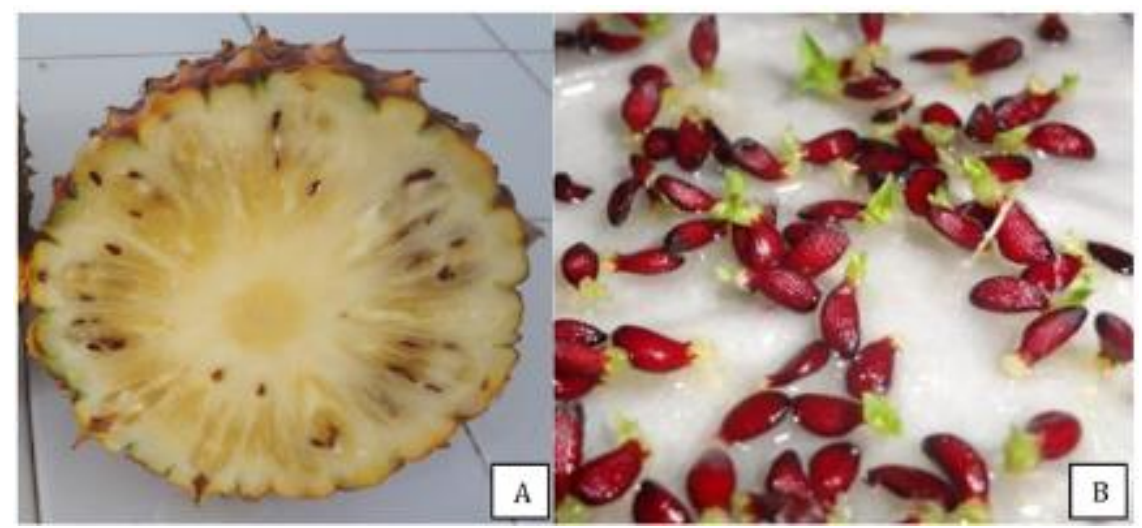

Figure 3 Seeds extracted in the over-ripe fruit (A) and germinated in plastic trays with blotting paper as a substrate (B). IPA's Pineapple Genetic Breeding Program. Photos Lira Júnior, J. S.

In April 2016, at 90 days after sowing, acclimatization process was started, when this seedlings were transplanted into styrofoam trays containing commercial substrate Plantmax HT, and maintained under a shedding screen (50\%) and micro-spray irrigation (Figure 4A).

At 100 days, after transplanting, these seedlings were individualized into black polyethylene bags $(15 \mathrm{~cm} \times 10 \mathrm{~cm})$ containing $2 / 3$ of soil $+1 / 3$ of tanned bovine manure, and maintained under full sun with micro-spray irrigation (Figure 
4B). This acclimatization period lasted for about 13 months, until May 2017, when seedlings reached approximately height of $30 \mathrm{~cm}$ suitable for field planting.

\subsection{Planting seedlings}

Field trial lasted for about 23 months (from 2017 May to 2019 April). This period started with planting of individuals in the simple spacing of $1.2 \mathrm{~m} \times 0.6 \mathrm{~m}$, and cultivated according to rainfed system (Figure 5). Fertilization were performed following results of the soil fertility analysis, as recommendations reported by [16]: $\mathrm{P}=5 \mathrm{mg} / \mathrm{dm}^{3} ; \mathrm{pH}=5,7\left(\mathrm{H}_{2} \mathrm{O}\right) ; \mathrm{Ca}=$ 3,7 cmolc.dm ${ }^{-3} ; \mathrm{Mg}=1,00 \mathrm{cmolc} . \mathrm{dm}^{-3} ; \mathrm{Na}=0,03 \mathrm{cmolc} \cdot \mathrm{dm}^{-3} ; \mathrm{K}=0,27 \mathrm{cmolc} \cdot \mathrm{dm}^{-3} ; \mathrm{Al}=0,00 \mathrm{cmolc}^{-\mathrm{dm}^{-3}} ; \mathrm{H}=5,36 \mathrm{cmolc}^{-\mathrm{dm}}{ }^{-}$ 3; $\mathrm{S}=5,00 \mathrm{cmolc} \cdot \mathrm{dm}^{-3} ; \mathrm{CTC}=10,40 \mathrm{cmolc} \cdot \mathrm{dm}^{-3}$. The rainfall data for cultivation period on the field are presented in the Table 2. Plants do not received treatment for floral induction, whose inflorescences naturally were emitted.

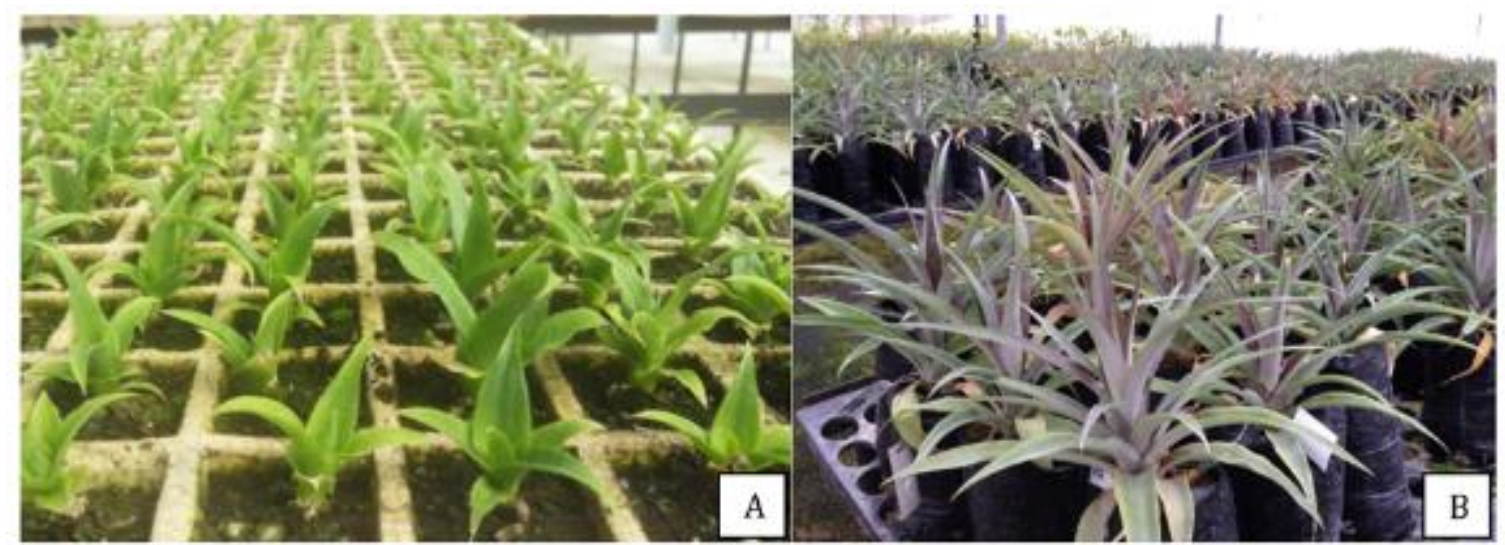

Figure 4 Transplanting (A) and acclimatization (B) of seedlings. IPA's Pineapple Genetic Breeding Program. Photos Lira Júnior, J. S.

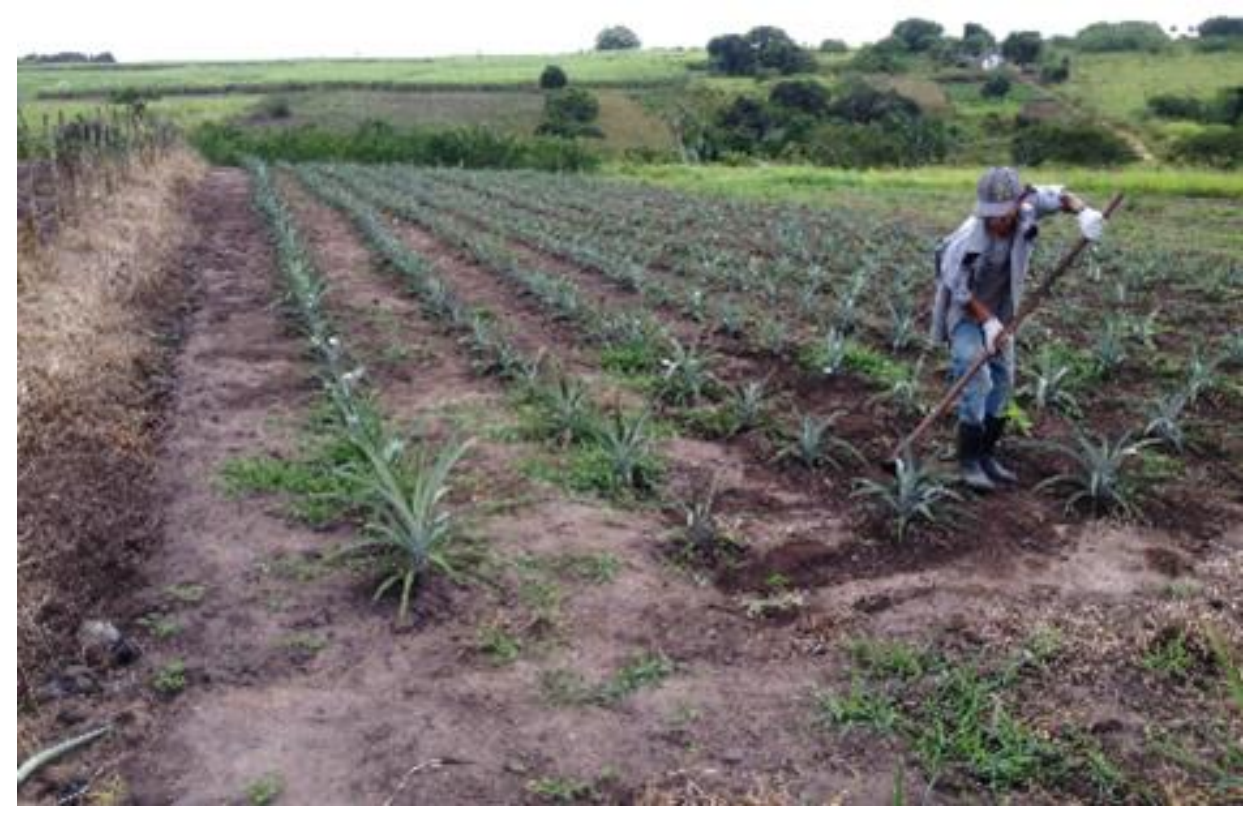

Figure 5 Cultivation of half-sib progeny propagated from seed (sexual cycle), and developed by the IPA's Pineapple Genetic Breeding Program. Experimental Station of Itambé, PE, Brazil. Photo Lira Júnior, J. S. 
Table 2 Monthly distribution of rainfall during the field cultivation period and historical monthly mean of 40 years. Agronomic Institute of Pernambuco State (IPA), Experimental Station of Itambé, Pernambuco State, Brazil.

\begin{tabular}{|l|l|l|l|l|l|l|l|l|l|l|l|l|l|}
\hline \multirow{2}{*}{ Period } & \multicolumn{10}{|c|}{ Month } & \multirow{2}{*}{ Totals } \\
\cline { 2 - 15 } & May & Jun & Jul & Aug & Sep & Oct & Nov & Dec & Jan & Feb & Mar & Apr & \\
\hline $2017 / 2018$ & 147 & 191 & 380 & 83 & 63 & 40 & 5 & 8 & 201 & 217 & 105 & 235 & 1,675 \\
\hline $2018 / 2019$ & 175 & 136 & 124 & 2 & 4.5 & 3 & 4.7 & 48 & 82 & 155 & 193 & 144 & 1,072 \\
\hline Mean* $^{*}$ & 154 & 216 & 191 & 93 & 58 & 28 & 21 & 27 & 65 & 68 & 124 & 154 & 1,204 \\
\hline
\end{tabular}

\subsection{Measured traits}

Individual plants at the time of the ripe fruit harvest were measured. Fruit maturation for harvest was determined visually, and considering at least $50 \%$ change on coloring of the shell from green to yellowish or orange.

The follow 17 traits were evaluated, which nine are related to the fruit: 1) FMWC = fruit mass without crown (g), 2) CM = crown mass (g), 3) FL = fruit length $(\mathrm{cm}), 4) \mathrm{CFB}=$ circumference of the fruit base $(\mathrm{cm}), 5) \mathrm{CFMT}=$ circumference of the fruit middle third $(\mathrm{cm}), 6) \mathrm{CFA}=$ circumference of the fruit apex $(\mathrm{cm}), 7) \mathrm{CL}=$ crown length $(\mathrm{cm}), 8) \mathrm{DCA}=$ diameter of the central axis ( $\mathrm{mm})$, and 9) SSC = soluble solids contents ( $\left.{ }^{\circ} \mathrm{Brix}\right)$; and eight are related to the plant: 10) PHFB = plant height to the fruit base $(\mathrm{cm}), 11) \mathrm{PH}=$ plant height $(\mathrm{cm}), 12) \mathrm{PL}=$ peduncle length $(\mathrm{cm}), 13) \mathrm{PD}=$ peduncle diameter $(\mathrm{mm}), 14) \mathrm{LL}=$ leaf length $\mathrm{D}(\mathrm{cm}), 15) \mathrm{LW}=$ leaf width $(\mathrm{cm}), 16) \mathrm{DSBL}=$ diameter of the stem base with leaves $(\mathrm{mm})$, 17) $\mathrm{NAL}=$ number of active leaves.

\subsection{Statistical analysis}

\subsubsection{Descriptive statistics and relative contribution}

The sampled data were used for calculate descriptive statistics for assessed fruit and plant traits: Mean $(\bar{X})$; minimum value (min. V.); maximum value (max. v.); standard deviation( $\hat{\sigma})$; coefficient of variation (CV\%); lower limit (LL) and upper limit (UL), at the confidence interval with probability of $95 \%$.

The methodology of Singh [17] relative contribution $\left(S_{. j}\right)$ for define which traits are most important for divergence among half-sib individuals was used, according to the following expression:

$$
\text { Equation (I) } \sum_{j=1} S_{. j}=\sum_{i<} \sum_{i \prime} d_{i i \prime \prime}^{2}
$$

where: $d_{i i}^{2}$ is the Square of the Standardized Euclidean Distance among half-sib individuals was estimated according to the following expression:

$$
\text { Equation (II) } d^{2}{ }_{i i^{\prime}}=\frac{1}{v} \sum_{j}\left(Y_{i j}-Y_{i^{\prime} j}\right)^{2},
$$

where: $Y_{i j}$ is the value of thei-th individual, regarding toj-th trait, and $v$ is the number of evaluated traits; Original data were standardized due to the different units of measurement, resulting in a mean $=0$ and variance $=1$, according to the following expression;

$$
\text { Equation (III) } y_{i j}=\frac{Y_{i j}}{\hat{\sigma}_{y j}}
$$

where: $\hat{\sigma}_{y j}$ is the standard deviation of the trait $Y$.

\subsubsection{Tocher's cluster optimization method}

In order to identify genitors to compose hybridization blocks and evaluation cycles of phenotypic stability for use per se, genetic diversity by estimating measures of dissimilarity was studied among individuals based on the 17 evaluated traits. Firstly, It was considered data set formed by those individuals with values $\geq$ than overall means for fruit mass 
without crown (FMWC) and soluble solids content (SSC). As reported by Cabral et al. $[3,18]$ to many importance traits for the genetic improvement of pineapples in Brazil, this selection was designed from these values for fruit mass without crown (FMWC) and soluble solids contents (SSC).

In sequence, measures of dissimilarity were obtained by estimating the Square of the Mean Euclidean Distance $\left(d_{i i^{\prime}}^{2}\right.$ Equation II) from the standardized data $\left(y_{i j}\right.$ - Equation III). The generated matrix was used in the cluster analysis by the Tocher optimization method, adopting as a criterion that the mean intragroup distance must be lower than the mean intergroup distance [12]. All statistical analyzes were performed using the software Genes [19].

\section{Results and discussion}

\subsection{Descriptive statistics and relative contribution}

Table 3 Descriptive statistics and Singh's relative contribution of plant and fruit traits measured on the 429 pineapple half-sib individuals, propagated by seeds (sexual cycle), under rainfed cultivation system. IPA-Experimental Station of Itambé, Pernambuco State, Brazil

\begin{tabular}{|c|c|c|c|c|c|c|c|c|}
\hline \multirow{2}{*}{ Traits } & \multirow{2}{*}{$\begin{array}{l}\text { CV } \\
(\%)\end{array}$} & \multicolumn{2}{|c|}{ Value } & \multirow{2}{*}{ Mean } & \multirow{2}{*}{$\begin{array}{l}\text { Standard } \\
\text { deviation }\end{array}$} & \multicolumn{2}{|c|}{ CI (95\%) } & \multirow{2}{*}{$\begin{array}{c}S_{. j} \\
(\%)\end{array}$} \\
\hline & & Min. & Max. & & & LL & UL & \\
\hline 1. Fruit & - & - & - & - & - & - & - & 52.69 \\
\hline FMWC(g) & 30.43 & 382.00 & $5,393.00$ & $1,992.10$ & 606.35 & $1,930.62$ & $2,050.65$ & 3.76 \\
\hline $\mathrm{CM}(\mathrm{g})$ & 63.79 & 10.00 & 360.00 & 90.96 & 58.03 & 85.08 & 96.57 & 7.06 \\
\hline $\mathrm{FL}(\mathrm{cm})$ & 24.31 & 10.80 & 48.20 & 23.73 & 5.77 & 23.14 & 24.28 & 6.12 \\
\hline $\mathrm{CFB}(\mathrm{cm})$ & 10.41 & 24.00 & 56.20 & 39.96 & 4.16 & 39.53 & 40.36 & 4.30 \\
\hline CFMT $(\mathrm{cm})$ & 9.89 & 25.80 & 51.20 & 38.21 & 3.78 & 37.82 & 38.57 & 5.70 \\
\hline $\mathrm{CFA}(\mathrm{cm})$ & 18.52 & 15.80 & 46.20 & 29.36 & 5.44 & 28.81 & 29.88 & 8.24 \\
\hline $\mathrm{CL}(\mathrm{cm})$ & 38.04 & 3.20 & 36.70 & 13.43 & 5.11 & 12.91 & 13.92 & 5.98 \\
\hline DCA (mm) & 22.56 & 10.00 & 42.00 & 20.47 & 4.62 & 20.00 & 20.91 & 5.35 \\
\hline $\mathrm{SSC}\left({ }^{\circ}\right.$ Brix $)$ & 16.38 & 9.60 & 26.40 & 15.93 & 2.61 & 15.66 & 16.18 & 6.18 \\
\hline 2. Plant & - & - & - & & - & - & - & 47.31 \\
\hline PHFB $(\mathrm{cm})$ & 15.45 & 18.20 & 68.40 & 46.12 & 7.13 & 45.39 & 46.80 & 5.18 \\
\hline $\mathrm{PH}(\mathrm{cm})$ & 18.07 & 30.30 & 114.10 & 79.55 & 14.38 & 78.09 & 80.93 & 7.56 \\
\hline $\mathrm{PL}(\mathrm{cm})$ & 16.14 & 9.7 & 34.7 & 19.29 & 3.11 & 18.97 & 19.59 & 3.99 \\
\hline $\mathrm{PD}(\mathrm{mm})$ & 18.10 & 16 & 61 & 31.63 & 5.72 & 31.04 & 32.17 & 4.16 \\
\hline $\mathrm{LL}(\mathrm{cm})$ & 13.53 & 54.6 & 118.4 & 85.76 & 11.60 & 84.58 & 86.88 & 8.50 \\
\hline $\mathrm{LW}(\mathrm{mm})$ & 13.68 & 39 & 88 & 60.33 & 8.25 & 59.49 & 61.12 & 7.29 \\
\hline $\mathrm{DSBL}(\mathrm{mm})$ & 14.99 & 36 & 152 & 83.89 & 12.57 & 82.61 & 85.09 & 3.02 \\
\hline NAL & 22.02 & 11 & 58 & 36.74 & 8.09 & 35.92 & 37.52 & 7.61 \\
\hline
\end{tabular}

$\mathrm{CV}=$ coefficient of variation; lower limit (LL) and upper limit (UL), at the confidence interval (CI) with probability of $95 \%$; $S_{. j}=$ relative contribution (\%); FMWC = fruit mass without crown; $\mathrm{CM}=$ crown mass; $\mathrm{FL}=$ fruit length; $\mathrm{CFB}=$ circumference of the fruit base; $\mathrm{CFMT}=$ circumference of the fruit middle third; CFA = circumference of the fruit apex; CL = crown length; DCA = diameter of the central axis; SSC = soluble solids contents; PHFB = plant height to the fruit base; $\mathrm{PH}=$ plant height; $\mathrm{PL}=$ peduncle length; $\mathrm{PD}=$ peduncle diameter; $\mathrm{LL}=$ leaf length $\mathrm{D} ; \mathrm{LW}=$ leaf width; DSBL = diameter of the stem base with leaves; NAL = number of active leaves.

Descriptive statistics based on phenotypic data revealed a high variation for fruit and plant traits (Table 3). This result is important because it indicates a high potential for selecting descendants with recombinant traits for fruit quality and agronomic attributes that were inherited from their parents ('Pérola', 'MD-2', 'BRS Imperial', and 'BRS Vitória').

Those traits that are related to the fruit reached coefficients of variation (CV's) between $9.89 \%$ and $63.79 \%$, which resulted amplitude of $53.90 \%$ and, consequently, revealed a wide dispersion of the data around the respective means (Table 3). Plant traits presented CV's from $13.53 \%$ to $22.02 \%$, which resulted an amplitude of $8.49 \%$ and, consequently, a lowest data dispersion, when it is compared to the group of fruit traits (Table 3). 
For example, a portion of this variation can be observed in the Figure 6 for fruit and plant traits among some individuals that were deloped by IPA's Pineapple Breeding Program.
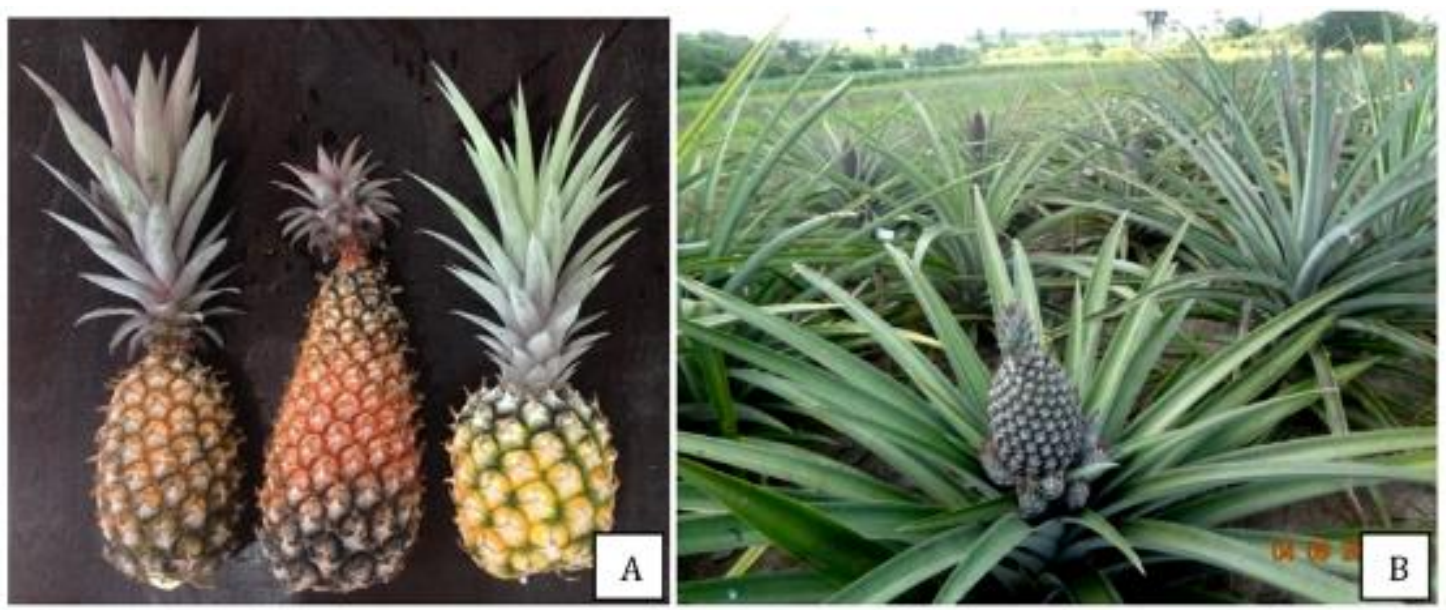

Figure 6 Sample of the phenotypic variation (coloring, shape, size, and growth habit) for fruit (A) and plant (B) traits among some half-sib individuals. IPA's Pineapple Genetic Breeding Program. Experimental Station of Itambé, PE, Brazil. Photos Lira Júnior, J. S.

Considering similar traits, these results are comparable to the CV's of $9.01 \%$ and $46.11 \%$, reported by Cabral et al. [18] for selected $F_{1}$ genotypes that by hybridization among different cultivars were obtained. These authors commented that high CV's are expected because they are hybrid progenies with a great variability among descendents. According to According to Chan [6], pineapple cultivars are heterozygous and hybridization among them often leads to development of fertile seeds that contains a wide spectrum of genotypic combinations. From this segregating $\mathrm{F}_{1}$ population it is possible to select excellent individuals with trait recombinants within a progeny composed by numerous descendants.

Among the fruit traits that reached the highest CV values: Crown mass (CM) varied from $10 \mathrm{~g}$ to $360 \mathrm{~g}$ with a standard deviation of $58.03 \mathrm{~g}$ around the mean of 90.96g; crown length (CL) varied from $3.2 \mathrm{~cm}$ to $36.7 \mathrm{~cm}$, which resulted in a standard deviation of $5.11 \mathrm{~cm}$, around the mean of $13.43 \mathrm{~cm}$; fruit mass without crown (FMWC) reached from $382 \mathrm{~g}$ to $5,393 \mathrm{~g}$ that resulted in a standard deviation of $606.35 \mathrm{~g}$ around the mean of $1,992.10 \mathrm{~g}$, and $95 \%$ confidence interval of $1,930.62 \mathrm{~g}$ to $2,050.65 \mathrm{~g}$ (Table 3 ).

Regarding the traits that achieved intermediate CV values: Fruit length (FL) varied from $10.8 \mathrm{~cm}$ to $48.2 \mathrm{~cm}$, whose standard deviation was $5.77 \mathrm{~cm}$ around the mean of $23.73 \mathrm{~cm}$; soluble solids contents (SSC) varied from $9.6^{\circ} \mathrm{Brix}$ to $26.40^{\circ} \mathrm{Brix}$, with standard deviation of $2.61^{\circ} \mathrm{Brix}$ around the mean of $15.93^{\circ} \mathrm{Brix}$ and $95 \%$ confidence interval of $15.66^{\circ}$ Brix to $16.18^{\circ} \mathrm{Brix}$; circumference of the fruit apex (CFA) reached from 15.80 to $46.20 \mathrm{~cm}$ with standard deviation of $5.44 \mathrm{~cm}$, around the mean of $29.36 \mathrm{~cm}$, and lower limit of $28.81 \mathrm{~cm}$ and upper limit of $29.88 \mathrm{~cm}$, at the confidence interval with probability of 95\%; diameter of the central axis (DCA) varied from $10 \mathrm{~mm}$ to $42 \mathrm{~mm}$, with standard deviation of $4.62 \mathrm{~mm}$ and around mean of $20.47 \mathrm{~mm}$.

Lowest $\mathrm{CV}$ values were achieved for circumferences of the fruit middle third (CFMT) and of the fruit base (CFB). Consequently, these traits stood out among those that exhibited the smaller variations: While CFMT varied from $25.80 \mathrm{~cm}$ to $51.20 \mathrm{~cm}$, with standard deviation of $3.78 \mathrm{~cm}$ around the mean of $38.21 \mathrm{~cm}$; CFB achieved mean of $39.96 \mathrm{~cm}$, ranging from $24.00 \mathrm{~cm}$ to $56.20 \mathrm{~cm}$ and standard deviation $4.16 \mathrm{~cm}$.

Amid plant traits that achieved the highest CV value: Number of active leaves (NAL) varied from 11 to 58 , with standard deviation of 8.08 around mean of 36.74 .

For those plant traits that reached the intermediate CV values: Peduncle diameter (PD) with mean of $31.63 \mathrm{~mm}$ and standart deviation of $5,72 \mathrm{~mm}$, achieved values between $16 \mathrm{~mm}$ and $61 \mathrm{~mm}$; Plant height (PH) presented standard deviation of $14.38 \mathrm{~cm}$ and mean of $79.55 \mathrm{~cm}$, with variation between $30.30 \mathrm{~cm}$ and $114.10 \mathrm{~cm}$; Peduncle length (PL) varied from $9.7 \mathrm{~cm}$ to $34.7 \mathrm{~cm}$, with standard deviation of $3.11 \mathrm{~cm}$, and around the mean of $19.29 \mathrm{~cm}$; Plant height to the fruit base (PHFB) presented variation from $18.20 \mathrm{~cm}$ to $68.40 \mathrm{~cm}$, standart deviation of $7.13 \mathrm{~cm}$, and around the mean $46.12 \mathrm{~cm}$. 
Regarding to plant traits which achieved the smallest CV values: diameter of the stem base with leaves (DSBL) with mean of $83.89 \mathrm{~mm}$ and standard deviation of $12.57 \mathrm{~mm}$, varied from $36 \mathrm{~mm}$ to $152 \mathrm{~mm}$; Leaf width (LW) varied from $39 \mathrm{~mm}$ to $88 \mathrm{~mm}$, with standart deviation of $8.25 \mathrm{~mm}$, and around the mean of $60.33 \mathrm{~mm}$; Leaf length (LL) varied from $54.6 \mathrm{~cm}$ to $118.4 \mathrm{~cm}$ with standart deviation of $11.60 \mathrm{~cm}$, and around mean of $85,86 \mathrm{~cm}$.

These results are within of the wide range from $85.38 \mathrm{~g}$ to $176.45 \mathrm{~g}$ for the mean crown weight and from $1,102.38 \mathrm{~g}$ to 1,857.27g for fruit weight [18], regarding to selected F1 genotypes in progenies from different crosses. According to Chan and Lee [20], fruit weight of $F_{1}$ pineapple hybrids selected for early fruiting varied from $1.36 \mathrm{~kg}$ to $1.73 \mathrm{~kg}$. According Nhat Hang et al. [13], from several $F_{1}$ hybrids three were better in terms of fruit cylinder shape, fruit weight (1,500g-1,760g), and edible portion (56.3\%-75.4\%). Lira Júnior et al. [21] reported genotypic values (BLUP) of pineapple hybrids between $1.60 \mathrm{~kg}$ and $2.72 \mathrm{~kg}$ for fruit mass without crown.

Regarding to plant traits, Cabral et al. [18] reported means between $29.63 \mathrm{~cm}$ and $61.18 \mathrm{~cm}$ for plant height and $16.37 \mathrm{~cm}$ a $27.14 \mathrm{~cm}$ for peduncle length. According to these authors, an elite pineapple cultivar must exhibits a smallest peduncle length than $20 \mathrm{~cm}$ to avoid sunburn and breakdown peduncle.

For soluble solids contents (SSC) these results (Table 3) exceed the mean values of $13.21^{\circ} \mathrm{Brix}$ at $14.99^{\circ} \mathrm{Brix}$ [18]. Lira Júnior et al. [21] reported genotypic values (BLUP) of $\mathrm{F}_{1}$ hybrids between $15.90^{\circ}$ Brix and $21.86^{\circ}$ Brix for soluble solids contents. According to Nhat Hang et al. [13], total soluble solids varied from $18.4 \%$ to $19.4 \%$ in a segregating progeny. Sripaoraya et al. [7] evaluated a total of $886 \mathrm{~F}_{1}$ individuals and three of them ranged from $18.0^{\circ} \mathrm{Brix}$ to $22.2^{\circ} \mathrm{Brix}$ for soluble solids contents.

Respecting to the relative contribution analysis, while fruit traits grouped $52.69 \%$ of the total variance, plant traits accumulated $47.31 \%$ (Table 3). The higher individual contributions were expressed by LL, CFA, NAL, PH, LW, CM, SSC, and FL traits, with values ranging from $6.00 \%$ to $8.50 \%$. In an intermediate group, CL, CFMT, DCA, PHFB, CFB, and DP traits contributed with values between $4 \%$ and $6 \%$. Despite these lower values of contributions, between 3\% and $4 \%$, PL, FMWC, and SD traits are important for relative importance study in the plant genetic breeding.

These results indicate that evaluated traits are essentials and contribute, relatively, for discrimination of the evaluated $\mathrm{F}_{1}$ individuals, being not recommended discard them for genetic divergence studies.

\subsubsection{Tocher's cluster optimization method}

Among the 429 individuals evaluated, 144 were used for genetic diversity analysis with high means for fruit mass without crown (FMWC) $\geq 1,992.10 \mathrm{~g}$ and soluble solids content (SSC) $\geq 15.93^{\circ}$ Brix. Tocher's optimization grouping analysis resulted in the formation of 12 heterotic groups (Table 4).

The largest number of 95 individuals (65.97\%) was gathered by group I, which contains individuals 04-62 and 04-23 with smallest distance measurement $\left(\mathrm{D}^{2}=0.0895\right)$ and, therefore, presented the least dissimilarity (Table 4). The maximum distance $\left(\mathrm{D}^{2}=5.1371\right)$ was estimated between individuals $125-274$ and $125-18$, respectively, clustered in groups VI and VII, with 5 and 4 individuals each group.

Group VII (125-363; 125-85; 04-60; 125-274) stood out for the highest averages for FMWC (4,244g), DCA (28.75mm), PD (46.75mm), and DSBL (107.50mm) (Table 5). In addition to other attributes, groups IX and VIII, which stood out for the highest averages for SSC of $21.10^{\circ}$ Brix and $20.80^{\circ}$ Brix, respectively, clustered individuals $125-40$; 125 -292; 125 218; 125-95; and 125-372. In addition to other attributes, groups IX and VIII, which stood out for the highest averages for SSC of $21.10^{\circ}$ Brix and $20.80^{\circ}$ Brix, respectively, clustered individuals $125-40 ; 125-292 ; 125-218$; $125-95$; and 125 372. The performance per se of these individuals should be evaluated with a view to recommending those with best performances and greatest phenotypic stability.

As reported by Melão et al. [8], the existence of genetic variability is essential to start a breeding program. From the analysis of genetic divergence, these authors suggested groups of pineapple accessions for hybridizations based on morphological and agronomic characteristics among 19 accessions of pineapple.

From the conception of a diverse genetic base population with high means, and satisfactory agronomic performance, it is possible to potentialize the heterosis effects, increasing the chances of selecting transgressive individuals [11,22]. 
Table 4 Clustering of 144 individuals of pineapple half-sibs by Tocher's optimization method using the Square of the Standardized Euclidean Distance based on 17 fruit and plant traits. IPA-Experimental Station of Itambé, Pernambuco State, Brazil

\begin{tabular}{|c|c|c|}
\hline Groups & $\begin{array}{l}\text { Number of } \\
\text { individuals }\end{array}$ & Identification \\
\hline I & 95 & $\begin{array}{l}04-62 ; 04-23 ; 04-08 ; 125-333 ; 125-354 ; 125-254 ; 125-235 ; 125-93 ; 125-144 ; \\
125-220 ; 125-276 ; 125-348 ; 125-211 ; 125-252 ; 125-26 ; 125-173 ; 04-85 ; 125- \\
133 ; 125-172 ; 125-76 ; 125-129 ; 125-347 ; 125-111 ; 125-192 ; 125-142 ; 125-158 \\
125-66 ; 125-191 ; 125-50 ; 125-217 ; 125-62 ; 125-364 ; 125-130 ; 125-97 ; 125-11 ; \\
125-65 ; 125-175 ; 125-281 ; 125-224 ; 04-102 ; 125-303 ; 125-236 ; 125-168 ; 125- \\
156 ; 125-43 ; 125-323 ; 04-14 ; 125-222 ; 125-05 ; 125-341 ; 125-150 ; 04-99 ; 125- \\
148 ; 04-84 ; 04-55 ; 04-95 ; 04-50 ; 03-26 ; 125-151 ; 04-64 ; 04-19 ; 125-337 ; 125- \\
124 ; 04-63 ; 125-202 ; 125-38 ; 125-247 ; 125-289 ; 125-371 ; 125-10 ; 125-277 ; 04- \\
106 ; 125-313 ; 04-32 ; 125-108 ; 04-54 ; 125-265 ; 04-72 ; 125-315 ; 125-241 ; 125-08 \\
04-11 ; 125-71 ; 125-57 ; 125-244 ; 125-338 ; 125-45 ; 125-286 ; 125-163 ; 125-128 \\
125-106 ; 125-51 ; 04-81 ; 04-92 ; 125-132\end{array}$ \\
\hline II & 14 & $\begin{array}{l}\text { 125-199; } 125-358 ; 125-114 ; 03-28 ; 04-39 ; 125-189 ; 04-103 ; 125-310 ; 125- \\
369 ; 125-178 ; 125-362 ; 125-304 ; 125-41 ; 125-70\end{array}$ \\
\hline III & 5 & $125-339 ; 125-20 ; 125-109 ; 125-343 ; 04-94$ \\
\hline IV & 5 & $125-250 ; 03-03 ; 125-283 ; 125-346 ; 125-257$ \\
\hline $\mathrm{V}$ & 4 & $125-110 ; 04-86 ; 125-330 ; 04-52$ \\
\hline $\mathrm{VI}$ & 5 & $125-210 ; 125-18 ; 04-57 ; 125-278 ; 125-314$ \\
\hline VII & 4 & $125-363 ; 125-85 ; 04-60 ; 125-274$ \\
\hline VIII & 3 & $125-218 ; 125-95 ; 125-372$ \\
\hline IX & 2 & $125-40 ; 125-292$ \\
\hline $\mathrm{X}$ & 5 & $125-42 ; 04-25 ; 125-256 ; 03-34 ; 125-320$ \\
\hline $\mathrm{XI}$ & 1 & $03-21$ \\
\hline XII & 1 & $03-23$ \\
\hline \multicolumn{2}{|c|}{ Maximum distance = 5.1371} & $125-274$ and $125-18$ \\
\hline \multicolumn{2}{|c|}{ Minimum distance $=0.0895$} & $04-62$ and $04-23$ \\
\hline
\end{tabular}

For example, in Figure 7 stands out individual 125-363 that is member of the heterotic group VII, at the time of harvest for analysis. It is observed that the plant is vigorous with spreading growth habit, and fruit has the potential for high pulp productivity, as the fruit mass without crown reached $3,905 \mathrm{~g}$ and soluble solids contents $16^{\circ} \mathrm{Brix}$. According to Lira Júnior [21], this same individual was selected and presented genotypic values (REML/BLUP) of 2.54kg for fruit mass without crown and $15.98^{\circ}$ Brix for total soluble solids (TSS), conical fruit shape, pulp's golden yellow coloration and spiny leaf margin spinescence.

These results indicate a high heterotic potential of the group VII with a very high mean for FMWC in future hybridization programs with groups IX and VIII, both with highlights for the high means of SSC. The high divergence between these analyzed groups, probably, is due to their genetic origin and the degree of parentage among evaluated individuals. The high level of genitor's heterozygosis with contrasting and complementary traits contributed possibly to this result, reproducing a high rate of recombination among half-sib descendents. 
Table 5 Means of fruit and plant traits for 12 groups of pineapple half-sibs formed by Tocher's optimization method using the Square of the Standardized Euclidean Distance. IPA-Experimental Station of Itambé, Pernambuco State, Brazil

\begin{tabular}{|l|c|c|c|c|c|c|c|c|c|c|c|c|}
\hline \multirow{2}{*}{ Traits } & \multicolumn{10}{|c|}{ Means/Group } \\
\cline { 2 - 13 } & I & II & III & IV & V & VI & VII & VIII & IX & X & XI & XII \\
\hline FMWC(g) & 2,271 & 2,331 & 3,029 & 2,218 & 3,228 & 2,192 & 4,244 & 2,142 & 2,111 & 2,589 & 3,095 & 2,410 \\
\hline CM(g) & 69.46 & 127.43 & 80.20 & 31.60 & 69.25 & 152.40 & 70.75 & 130.00 & 158.50 & 60.80 & 205.00 & 81.00 \\
\hline FL (cm) & 26.72 & 21.44 & 36.06 & 28.90 & 27.10 & 23.44 & 38.28 & 28.33 & 20.70 & 27.50 & 22.70 & 23.00 \\
\hline CFB (cm) & 41.62 & 43.91 & 44.12 & 40.16 & 48.60 & 42.00 & 49.13 & 38.89 & 37.00 & 43.42 & 50.40 & 45.00 \\
\hline CFMT (cm) & 38.74 & 43.68 & 39.98 & 36.88 & 46.58 & 41.20 & 46.00 & 35.63 & 41.20 & 40.82 & 49.20 & 42.80 \\
\hline CFA (cm) & 28.21 & 37.41 & 22.34 & 24.56 & 35.90 & 35.84 & 22.90 & 24.80 & 37.00 & 25.02 & 38.00 & 30.40 \\
\hline CL (cm) & 11.96 & 17.69 & 14.08 & 7.62 & 11.40 & 22.32 & 10.53 & 12.90 & 17.40 & 11.58 & 11.30 & 8.40 \\
\hline DCA (mm) & 20.52 & 24.93 & 22.20 & 18.40 & 20.00 & 26.40 & 28.75 & 22.33 & 21.00 & 23.20 & 18.00 & 16.00 \\
\hline SSC ( ${ }^{\circ}$ Brix) & 16.79 & 17.59 & 15.64 & 18.36 & 15.50 & 15.92 & 16.45 & 20.80 & 21.10 & 18.16 & 16.20 & 17.00 \\
\hline PHFB (cm) & 47.53 & 46.74 & 49.74 & 55.04 & 44.33 & 46.68 & 50.63 & 55.90 & 52.75 & 41.28 & 46.40 & 58.40 \\
\hline PH (cm) & 81.77 & 81.64 & 93.54 & 83.84 & 84.15 & 90.24 & 85.58 & 95.00 & 97.20 & 78.74 & 88.60 & 108.20 \\
\hline PL (cm) & 19.21 & 19.30 & 19.60 & 18.24 & 16.48 & 20.14 & 16.08 & 22.87 & 19.35 & 15.40 & 16.40 & 24.60 \\
\hline PD (mm) & 33.37 & 33.64 & 32.60 & 35.80 & 30.50 & 33.40 & 46.75 & 37.67 & 37.00 & 34.60 & 30.00 & 31.00 \\
\hline LL (cm) & 88.99 & 84.71 & 107.54 & 80.96 & 83.35 & 100.36 & 101.18 & 90.97 & 79.80 & 90.78 & 87.30 & 101.20 \\
\hline LW (mm) & 61.60 & 64.93 & 66.00 & 53.80 & 57.50 & 65.40 & 71.75 & 66.00 & 52.00 & 70.40 & 54.00 & 74.00 \\
\hline DSBL (mm) & 88.09 & 88.71 & 92.60 & 86.60 & 93.50 & 90.80 & 107.50 & 95.67 & 89.00 & 89.60 & 85.00 & 82.00 \\
\hline NAL & 38.24 & 43.86 & 39.00 & 47.60 & 39.25 & 35.20 & 49.75 & 45.00 & 52.00 & 46.80 & 54.00 & 32.00 \\
\hline
\end{tabular}

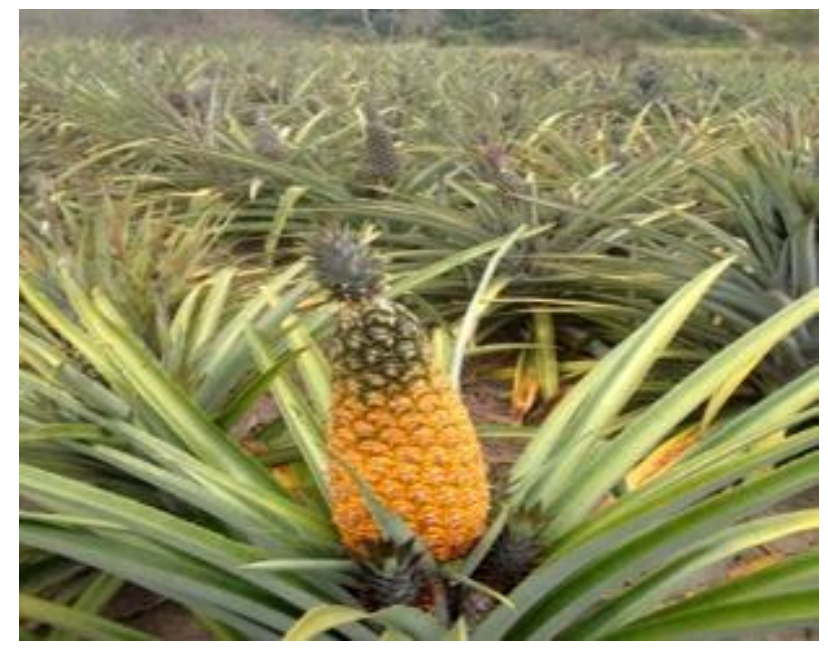

Figure 7 Fruit maturation of the hybrid IPA 125-363 from the base to the top. Experimental Station of Itambé, PE, Brazil. Photo Lira Júnior, J. S. 


\section{Conclusion}

Concerning to phenotypic variation, crown mass (CM), crown length (CL) and fruit mass without crown (FMWC) reach the largest data dispersions, while circumference of the fruit middle third (CFMT) and circumference of the fruit base (CFB) achieve the smallest;

Respecting to the relative importance for the total variance, both groups of traits gather almost the same proportions. While fruit traits cluster $52.69 \%$ of the total variance, plant traits accumulate $47.31 \%$. Individually, none of them should be discarded for the genetic divergence studies among pineapple half-sibs;

Group VII (125-363, 125-85, 04-60, and 125-274), group IX (125-40 and 125-292) and group VIII (125-218, 125-95, and 125-372) are recommended to compose hybridization blocks and evaluation cycles of phenotypic stability for use per se. These groups have a broad heterotic potential, and desirable agronomic traits, mainly regarding to high means for fruit mass without crown (FMWC) upper than 4,000g and soluble solids content (SSC) around $20-21^{\circ} \mathrm{Brix}$, which can be used by the IPA's pineapple breeding program.

\section{Compliance with ethical standards}

\section{Acknowledgments}

The authors would like to thank Science and Technology Support Foundation of the Pernambuco State (FACEPE), for financial support.

\section{Disclosure of conflict of interest}

There is no conflict of interest.

\section{References}

[1] FAO. Agricultural Data base, Crops [Internet]. Genebra: FAOSTAT; 2019 [cited 2021 abr 02].

[2] Reinhardt DHRC, Bartholomew DP, Souza FVD, Carvalho ACPP, Pádua, TRP, Junghans DT, Matos AP. Advances in pineapple plant propagation. Revista brasileira de fruticultura. 2018; 40(6): e-302.

[3] Cabral JRS, Matos AP, Jughans DT, Souza FVD. Pineapple Genetic Improvement In Brazil. Acta horticulturae. 2009; 822(2): 39-46.

[4] Ventura JA, Costa H, Cabral JRS, Matos AP. 'Vitória': New pineapple cultivar resistant to fusariosis. Acta horticulturae. 2009; 822(4): 51-56.

[5] Reinhardt DH, Cabral JRS, Matos AP, Junghans DT. 'BRS Ajubá', a new pineapple cultivar resistant to fusariosis and adapted to subtropical conditions. Acta horticulturae. 2012; 928(7): 75-79.

[6] Chan YK. Hybridization and selection in pineapple improvement: The experience in Malaysia. Acta horticulture. 2006; 702(1): 87-92.

[7] Sripaoraya S, Davey MR, Srinives P. F1 Hybrid pineapple resistant to bialaphos herbicide. Acta horticulture. 2011; 902(1): 201-207.

[8] Melão AV, Pereira MG, Krause W, Gonçalves LSA, Moreira WG. Agronomic and genetic divergence among accessions of pineapple under the conditions of the state of Mato Grosso. Revista brasileira de fruticultura. 2015; 37(4): 952-960.

[9] Wang JS, He JH, Chen HR, Chen YY, Qiao F. Genetic diversity in various accessions of pineapple [Ananas comosus (L.) Merr.] using ISSR and SSR markers. Biochemical genetics. 2017; 55(5-6): 347-366.

[10] Ismail SN, Ghani NSA, Razak SFA, Abidin RAZ, Yusof MFM, Zubir MN, Zainol R. Genetic Diversity of Pineapple (Ananas comosus) Germplasm in Malaysia Using Simple Sequence Repeat (SSR) Markers. Tropical life sciences research. 2020; 31(3): 15-27.

[11] Falconer DS. Introduction to quantitative genetics. 3nd ed. New York: Longman Scientific and Technical. 1989.

[12] Cruz CD, Regazzi AJ, Carneiro PCS. Biometric models applied to genetic improvement. 3rd ed. (vol. 2). Viçosa: Editora Viçosa. 2014. 
[13] Nhat Hang NT, Diem NTN, Chau NM. Pineapple breeding for quality improvement in South Vietnam. Acta horticulture. 2011; 902(1): 115-121.

[14] Sanewski GM, Coppens D’Eeckenbrugge G, Junghans DT. Varieties and Breeding. In: Sanewski GM, Bartholomew DP, Paull RE, eds. The Pineapple: Botany, Production and Uses. 2nd ed. Boston: CAB International. 2018; 42-84.

[15] Junghans DT. Cultivars. In: Santos CEM, Borém A, eds. Pineapple from planting to harvest. 1st ed. Viçosa: Editora UFV. 2019; 40-52.

[16] Bezerra JEF, Silva Júnior JF. Abacaxi. In: Cavalcanti FJA, ed. Fertilizer recommendations for the Pernambuco State: $2^{\mathrm{a}}$ aproximação. Recife: Agronomic Institute of Pernambuco. 2008; 83.

[17] Singh D. The relative importance of characters affecting genetic divergence. The Indian journal of genetics and plant breeding. 1981; 41: 237-245.

[18] Cabral JRS, Ledo CAS, Caldas RC, Junghans DT. Characters variation in pineapple hybrids obtained by different crosses. Revista brasileira fruticultura. 2009; 31(4): 1129-1134.

[19] Cruz CD. Genes Software - extended and integrated with the R, Matlab and Selegen. Acta scientiarum. Agronomy. 2016; 38(4): 547-552.

[20] Chan YK, Lee HK. Performance of F1 pineapple hybrids selected for early fruiting. Journal of tropical agriculture and food science. 1999; 27(1): 1-8.

[21] Lira Júnior JS, Bezerra JEF, Andrade DEGT. Selection of pineapple hybrids via genotypic values (REML/BLUP) for fruit mass and total soluble solids. World journal of advanced research and reviews. 2021; 09(03): 48-55.

[22] Cruz CD, Ferreira MF, Pessoni LA. Biometrics applied to the study of genetic diversity. 1st ed. Visconde do Rio Branco: Suprema. 2011. 